\title{
Biomimetic Synthesis of Cbz-(S)-Dolaphenine
}

\author{
Pablo García-Reynaga and Michael S. VanNieuwenhze* \\ Department of Chemistry, Indiana University, 800 E. Kirkwood Ave., Bloomington, IN, 47405, \\ USA
}

\begin{abstract}
A new route to $\mathrm{Cbz}-(S)$-dolaphenine, a recurring element in bioactive peptidic natural products, has been implemented, which closely parallels the biogenetic pathway. Cyclodehydration of $\mathbf{1 1}$ to yield thiazoline 2 allows for a $\mathrm{Ni}(0)$-promoted decarbonylative aromatization to provide the thiazole framework with retention of stereochemistry.
\end{abstract}

\section{Keywords}

Thiazole; Biomimetic; Thiazoline; Cyclodehydration; Decarbonylation

\begin{abstract}
The marine shell mollusk Dollabella auricularia is the source of a wealth of thiazolecontaining chemical agents with exceptional cytotoxic ability. ${ }^{1,2}$ One of the most pharmaceutically promising members of this family of bacteriocins has been dolastatin 10 , recently reaching Phase II clinical trials (Figure 1). ${ }^{3,4}$ First isolated by Pettit and coworkers, ${ }^{5}$ dolastatin 10 exerts its cytoxic activity by inhibiting microtubule assembly, binding tubulin at a site distinct from other antimitotic agents. ${ }^{6,7}$ It additionally exhibits potent proapoptotic effects in some drug-resistant cancer cell lines. ${ }^{8}$ As expected, derivatives of dolastatin 10 have also shown promise as medicinal agents, ${ }^{9}$ with additional evidence suggesting that they may be used in combination therapy given their synergistic activity with largazole, an HDAC inhibitor. ${ }^{10}$
\end{abstract}

Not surprisingly, related heterocyclic compounds also display strong medicinal potential. Virenamide $\mathrm{B}$, for example, exhibits strong cytotoxicity with $\mathrm{IC}_{50}$ values of $5 \mu \mathrm{g} / \mathrm{mL}$ against P388, A549, HT29, and CV1 cell lines. Perhaps the most outstanding member of this class is bottromycin A2, which has shown exceptional activity against methicillin-resistant Streptococcus aureus (MRSA, MIC $=1.0 \mu \mathrm{g} / \mathrm{mL}$ ) and vancomycin-resistant Enterococci (VRE, MIC $<1.0 \mu \mathrm{g} / \mathrm{mL}$ ). Bottromycin A2 inhibits protein biosynthesis by blocking the binding of aminoacyl tRNA to the A site on the 50S ribosome. ${ }^{11}$

The product of hybrid PKS-NRPS machinery, the structure of dolastatin 10 incorporates acetyl as well as peptidic frameworks, including the presence of the descarboxythiazole

(C) 2012 Elsevier Ltd. All rights reserved.

*Corresponding author. Tel.: +1-812-856-7545; fax: +1-812-855-8300; mvannieu@indiana.edu.

Supplementary Material

Experimental Procedures and characterization data for all new compounds are provided. Supplementary data associated with this article can be found in the online version at doi:(insert doi).

Publisher's Disclaimer: This is a PDF file of an unedited manuscript that has been accepted for publication. As a service to our customers we are providing this early version of the manuscript. The manuscript will undergo copyediting, typesetting, and review of the resulting proof before it is published in its final citable form. Please note that during the production process errors may be discovered which could affect the content, and all legal disclaimers that apply to the journal pertain. 
functionality, dolaphenine (Doe). This functionality, as well as its variants, is widely distributed across the range of products isolated from marine bacteria (Figure 1).

By virtue of their common descarboxythiazole motif, dolastatin 10 and its congeners represent a unified class of compounds with medicinal and biological appeal. Enzymatic decarboxylations are widespread in nature, ${ }^{12-14}$ and occur through different mechanisms, although examples of oxidative decarboxylations for the production of enamide-type products are known. ${ }^{15,16}$ It has been postulated that, in the case of barbamide, BarJ is responsible for the oxidative decarboxylation of a thiazoline-4-carboxylic acid intermediate as the final step to N-methyl-dolaphenine biogenesis. Given the putative generation of an enethiolate intermediate during aminovinylcysteine (AviMeCys) biosynthesis, ${ }^{17}$ the mechanism for oxidative decarboxylation in barbamide and dolastatin 10 may follow a similar pathway. ${ }^{18}$

Due to its widespread occurrence in the abovementioned series of medicinally promising metabolites, numerous syntheses of the dolaphenine subunit have been reported. ${ }^{19-25}$ By far the greatest synthetic challenge to the synthesis of dolaphenine has been the ability to secure the stereochemical purity of the stereocenter adjacent to the $\mathrm{C}-2$ position of the thiazole unit, either by its introduction with chiral auxiliaries or by its retention, starting from enantiomerically pure substrates. The majority of the successful approaches have been geared toward the former given the facile lability of this stereocenter. ${ }^{26}$

Most notably, Shioiri and Hamada have reported various studies on the synthesis of this unit. ${ }^{19,20}$ Traditional approaches, such as the condensation of aldehydes with aminothiols, followed by oxidation of the resulting thiazolidine with excess manganese dioxide returned low yields of the desired product along with considerable degradation of stereochemical integrity ( $77 \%$ ee). Excessive loss of stereochemical purity (56\% ee) was also observed with the modified Hantzch method, which had served well previously to produce optically pure 4-carboxy thiazoles. ${ }^{27}$

Collectively, these examples illustrate that there is still a need for an efficient and general synthesis of the dolaphenine unit. Given our desire to evaluate the oxidative decarboylation step leading to the descarboxythiazole motif in the abovementioned family of natural products, we envisioned that a route paralleling the biosynthetic pathway would best serve our purpose. This would potentially have the additional advantage of deriving chirality from the widely accessible pool of $L$ and $D$ amino acids, providing the rest of the dolaphenine congeners via simple amino acid substitution.

As outlined in Scheme 1, we envisioned a direct pathway to the installation of the thiazole unit via an oxidative decarbonylation reaction, employing a strategy developed recently in our group for the synthesis of enamides from amino acids. ${ }^{28}$ The requisite thiazoline, $\mathbf{2}$, was then envisioned to arise through sequential condensation reactions between appropriately protected phenylalanine and cysteine subunits. The major obstacle to this approach was anticipated to be the control of stereochemical integrity during these condensation events.

Our investigation began with assessing the stereoconservative construction of activated thiazoline $\mathbf{2}$, evaluating first the thioesterification of thiazoline acid $\mathbf{7}$ as the leading strategy. In this aim, coupling of Cbz-Phe-OSu (3) with $\mathrm{H}-\mathrm{Cys}(\mathrm{Trt})-\mathrm{OH}$, followed by esterification of the resulting acid with allyl bromide secured dipeptide 5 (Scheme 2). Thiazoline formation was subsequently effected through Kelly's conditions, employing the catalyst resulting from the combination of $\mathrm{Ph}_{3} \mathrm{PO}$ and $\mathrm{Tf}_{2} \mathrm{O},{ }^{29}$ which afforded thiazoline allyl ester $\mathbf{6}$ as a single diastereomer in good yield (67\%, 3 steps). Cleavage of the allyl ester protecting group cleanly produced the requisite acid, 7, which was ready for transformation into thioester 2. 
Thioesterification of $\mathbf{7}$, without compromising stereochemical integrity proved to be problematic, however. In the event, activation of the acid with DCC produced the desired thioester functionality, albeit with significant amounts of epimerization of the stereocenter alpha to C-2 of the thiazoline moeity. Monitoring of the thioesterification reaction by HPLC revealed that extensive epimerization had occurred within $1 \mathrm{~h}$ of reaction time $(1.3: 1 \mathrm{dr})$ in favor of the undesired diastereomer. While it was possible to separate these diastereomers, the lability of this compound towards epimerization was further illustrated by the fact that the pure diastereomers reverted to the same 1:1 diastereomeric mixture of upon standing in chloroform or silica, as observed by HPLC and NMR analysis.

Nevertheless, the diastereomeric mixture of $\mathbf{2}$ allowed for the assessment of the oxidative decarbonylation leading to dolaphenine. In the event, we were pleased to observe the formation of the requisite double bond expected under the Pd-catalyzed reaction conditions developed earlier, albeit in low yield. Increasing the reaction temperature did not improve yields despite the observation of complete consumption of starting material. ${ }^{30}$ Additionally, the near zero optical rotation of the product, $r a c-1$, confirmed epimerization had indeed taken place at the Phe stereocenter.

In light of these observations, we turned our attention to improving the synthesis of thioester 2 by means of installing the thioester functionality prior to thiazoline formation, with the expectation that we would find less erosion of stereochemical integrity. Thus, thioester $\mathbf{8}$ was cleanly prepared in 2 steps from acid 3 in $89 \%$ yield (Scheme 3 ).

Kelly's conditions were initially investigated given their established reputation for providing excellent retention of diastereomeric purity during the cyclodehydration process. Thus, the thioester was subjected to the action of $\mathrm{Ph}_{3} \mathrm{PO}-\mathrm{Tf}_{2} \mathrm{O}$ at $-18{ }^{\circ} \mathrm{C}$ for $2 \mathrm{~h}$ (Scheme 3).

Unfortunately, a diastereomeric mixture of thiazoline 2 (ca. 1.1:1) was again observed in addition to low yields of the desired product. Furthermore, increasing reaction temperatures gave similar ratios of diastereomers, without an improvement in yield, along with an increasing amount of undesired byproducts. In order to assess whether the steric hindrance of the trityl protecting group hindered the cyclodehydration step, we prepared the 2,4,6trimethoxybenzyl (Tmob)-protected cysteinyl dipeptide 10. Unfortunately, similar reactivity and diastereomer ratios were observed when $\mathbf{1 0}$ was subjected to Kelly's conditions.

Since the $\mathrm{Ph}_{3} \mathrm{PO}-\mathrm{Tf}_{2} \mathrm{O}$ system results in the generation of a strongly acidic reaction solution - TfOH is generated to cleave the thiol protecting group prior to the cyclodehydration step -we were prompted to examine a stepwise approach to heterocycle formation. Thus, Tmob-protected cysteinyl peptide 10 was treated with $10 \% \mathrm{TFA} / \mathrm{CH}_{2} \mathrm{Cl}_{2}$ using triethylsilane as a cation capture reagent to smoothly provide the pure and isolated thiol, 11. Upon treatment of this thiol with Ishihara's dehydration catalyst, ${ }^{31}$ we were delighted to find that, under optimized conditions, the desired product 2 could be isolated in $76 \%$ yield, along with minimal amounts of the undesired diastereomer 12 (Scheme 4). Notably, it was observed that with extended reaction times, the initially formed thiazoline $\mathbf{2}$ steadily epimerized. Furthermore, catalyst loading correlated strongly with both the yield and optical purity of the resulting product. In particular, employing less than $10 \%$ catalyst loadings yielded significantly increased amounts of the undesired diastereomer (ca. 86\% yield, 1:1 dr after 1 $\mathrm{hr}$ of reaction time). Although higher catalyst loadings were not examined, our observations suggest that further increases in catalyst loading may produce better results.

With this result in hand, we proceeded to examine the decarbonylation of 2 to $(S)$ dolaphenine using the milder conditions employing $\mathrm{Ni}(0)$ as the catalyst. In the event, we were delighted to observe that the major diastereomer 2 provided $\mathrm{Z}-(S)$-dolaphenine in $88 \%$ yield after stirring in a solution of $\mathrm{Ni}\left(\mathrm{PPh}_{3}\right)_{4}$ and $\mathrm{CuTC}$ at room temperature over $22 \mathrm{~h}$, 
while the minor diastereomer 12 provided Z-( $R$ )-dolaphenine (Scheme 4). Importantly, the optical rotation of this product proved to be in excellent agreement with that of the pure substrate. ${ }^{19}$ This further illustrates the efficiency of these conditions in providing for the mild decarbonylation of thioester substrates.

In an attempt to mitigate epimerization of the thiazoline intermediate by installing the required oxidation state prior to cyclodehydration, we carried out decarbonylation of thioester 10 to give the Tmob-protected enethiol 14 in modest yields (Scheme 5). Unfortunately, our preliminary attempts to induce the subsequent cyclodehydration with $\mathrm{Ph}_{3} \mathrm{PO}-\mathrm{Tf}_{2} \mathrm{O}$ did not yield the desired thiazole.

In summary, we have developed an efficient synthesis of Z-(S)-dolaphenine in a total of 5 steps with an overall yield of $52 \%$. The route is adaptable to the synthesis of dolaphenine congeners via substitution of phenylalanine for other amino acids. In addition, the results presented in this manuscript further demonstrate the utility of our recently developed method for oxidative decarbonylation of thioester precursors. ${ }^{28}$ Furthermore, the intermediates produced during the course of this work can be used as probes to study the enzymes responsible for oxidative decarboxylation in the dolaphenine (and related) biosynthetic pathway(s). Results toward this end will be presented in due course.

\section{Supplementary Material}

Refer to Web version on PubMed Central for supplementary material.

\section{Acknowledgments}

Financial support was provided by the NIH (AI 059327) and Indiana University is gratefully acknowledged. P.G.R. thanks Eli Lilly and Company for fellowship support. We also thank Professors Kenneth G. Caulton and David R. Williams (Indiana University) for helpful discussions.

\section{References}

1. Yamada K, Kigoshi H. Bull Chem Soc Jap. 1997; 70:1479.

2. Simmons TL, Andrianasolo E, McPhail K, Flatt P, Gerwick WH. Mol Cancer Ther. 2005; 4:333. [PubMed: 15713904]

3. Vaishampayan U, Glode M, Du W, Kraft A, Hudes G, Wright J, Hussain M. Clinical Cancer Research. 2000; 6:4205. [PubMed: 11106233]

4. Perez E, Hillman D, Fishkin P, Krook J, Tan W, Kuriakose P, Alberts S, Dakhil S. Investigational New Drugs. 2005; 23:257. [PubMed: 15868383]

5. Pettit GR, Kamano Y, Herald CL, Fujii Y, Kizu H, Boyd MR, Boettner FE, Doubek DL, Schmidt JM, Chapuis J-C, Michel C. Tetrahedron. 1993; 49:9151.

6. Bai RL, Pettit GR, Hamel E. J Biol Chem. 1990; 265:17141. [PubMed: 2211617]

7. Bai R, Petit GR, Hamel E. Biochemical Pharmacology. 1990; 39:1941. [PubMed: 2353935]

8. Aherne GW, Hardcastle A, Valenti M, Bryant A, Rogers P, Pettit GR, Srirangam JK, Kelland LR. Cancer Chemotherapy and Pharmacology. 1996; 38:225. [PubMed: 8646796]

9. Akashi Y, Okamoto I, Suzuki M, Tamura K, Iwasa T, Hisada S, Satoh T, Nakagawa K, Ono K, Fukuoka M. Br J Cancer. 2007; 96:1532. [PubMed: 17473826]

10. Taori K, Liu Y, Paul VJ, Luesch H. ChemBioChem. 2009; 10:1634. [PubMed: 19514039]

11. Shimamura H, Gouda H, Nagai K, Hirose T, Ichioka M, Furuya Y, Kobayashi Y, Hirono S, Sunazuka T, Ōmura S. Angew Chem Int Ed. 2009; 48:914.

12. Kaminaga Y, Schnepp J, Peel G, Kish CM, Ben-Nissan G, Weiss D, Orlova I, Lavie O, Rhodes D, Wood K, Porterfield DM, Cooper AJL, Schloss JV, Pichersky E, Vainstein A, Dudareva N. J Biol Chem. 2006; 281:23357. [PubMed: 16766535]

13. Liu D, Hwang C-C, Cook PF. Biochemistry. 2002; 41:12200. [PubMed: 12356322] 
14. Yoshida M, Fukuhara N, Oikawa T. J Bacteriol. 2004; 186:6855. [PubMed: 15466039]

15. Rachid S, Revermann O, Dauth C, Kazmaier U, Müller R. J Biol Chem. 2010; 285:12482. [PubMed: 20080978]

16. Brady SF, Chao CJ, Clardy J. J Am Chem Soc. 2002; 124:9968. [PubMed: 12188643]

17. Sit CS, Yoganathan S, Vederas JC. Acc Chem Res. 2011; 44:261. [PubMed: 21366289]

18. Sinha Roy R, Gehring AM, Milne JC, Belshaw PJ, Walsh CT. Nat Prod Rep. 1999; 16:249. [PubMed: 10331285]

19. Hamada Y, Hayashi K, Shioiri T. Tet Lett. 1991; 32:931.

20. Irako N, Hamada Y, Shioiri T. Tetrahedron. 1992; 48:7251.

21. Bredenkamp MW, Holzapfel CW, Snyman RM, van Zyl WJ. Syn Commun. 1992; 22:3029.

22. Irako N, Hamada Y, Shioiri T. Tetrahedron. 1995; 51:12731.

23. Pettit GR, Hogan F, Burkett DD, Singh SB, Kantoci D, Srirangam J, Williams MD. Heterocycles. 1994; 39:81.

24. Moody CJ, Hunt JCA. Synlett. 1999; 1999:984.

25. Mordant C, Reymond S, Tone H, Lavergne D, Touati R, Ben Hassine B, Ratovelomanana-Vidal V, Genet J-P. Tetrahedron. 2007; 63:6115.

26. Wipf P, Fritch PC. Tet Lett. 1994; 35:5397.

27. Schmidt U, Gleich P, Griesser H, Utz R. Synthesis. 1986; 1986:992.

28. García-Reynaga P, Carrillo AK, VanNieuwenhze MS. Org Lett. 2012; 14:1030. [PubMed: 22296268]

29. You SL, Razavi H, Kelly JW. Angew Chem. 2003; 115:87.

30. The major reaction product obtained was carboxylic acid arising from thioester hydrolysis. This is likely due to rate limiting decarbonylation and hydrolysis of the acylpalladium(II) intermediate.

31. Sakakura A, Kondo R, Umemura S, Ishihara K. Tetrahedron. 2009; 65:2102. 
<smiles>CCC(C)[C@H]([C@H](CC(=O)N[C@H](Cc1ccccc1)c1nccs1)OC)N(C)C(=O)[C@@H](NC(=O)[C@H](C(C)C)N(C)C)C(C)C</smiles><smiles></smiles>

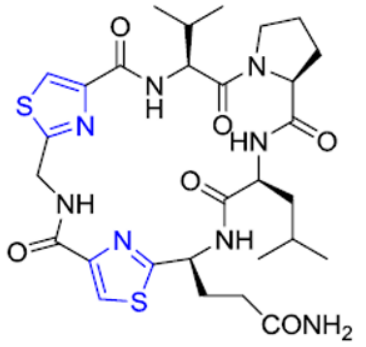<smiles>CO/C(=C/C(=O)N(C)[C@H](Cc1ccccc1)c1nccs1)CC(C)C(Cl)(Cl)Cl</smiles><smiles>C=CC(C)(C)N[C@@H](Cc1ccccc1)C(=O)N[C@@H](Cc1ccccc1)C(=O)N[C@H](c1nccs1)C(C)C</smiles>

Dolastatin 3

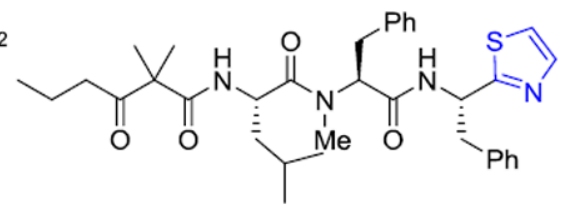

Dolastatin 18

Figure 1.

Dolastatin 10 and related cyanobacterial metabolites 


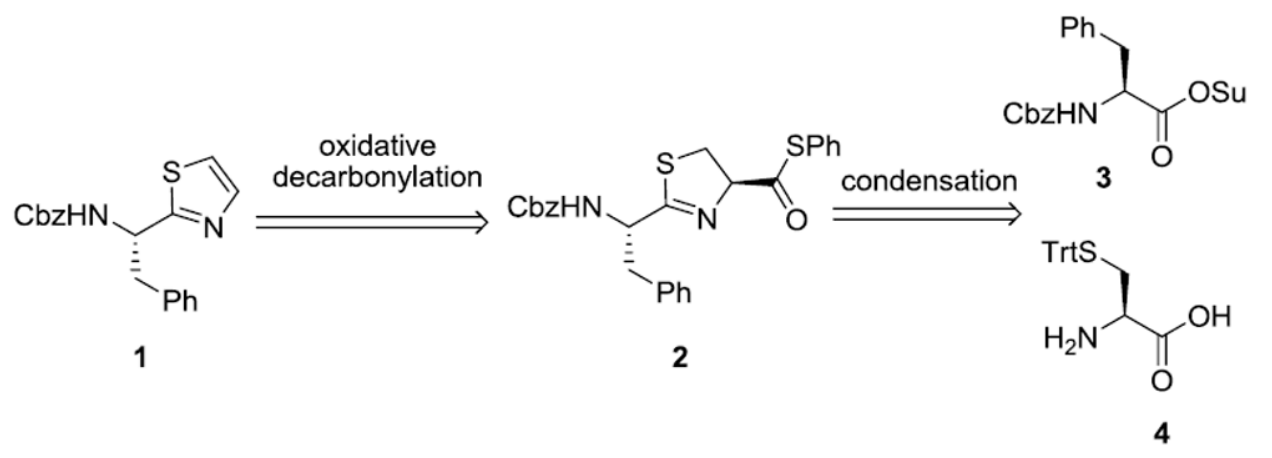

Scheme 1.

Synthetic route to Z-(S)-dolaphenine. 


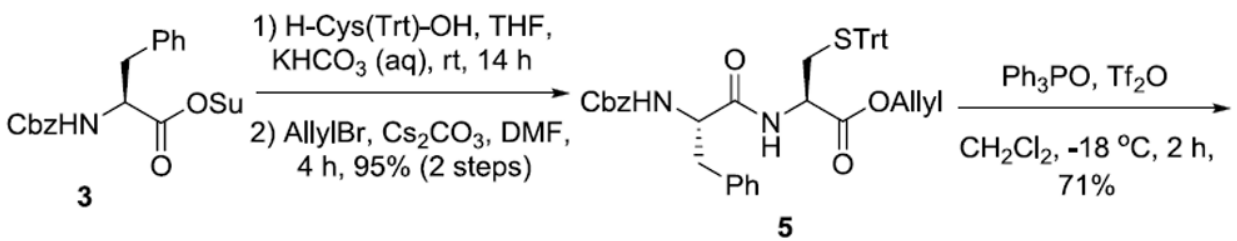

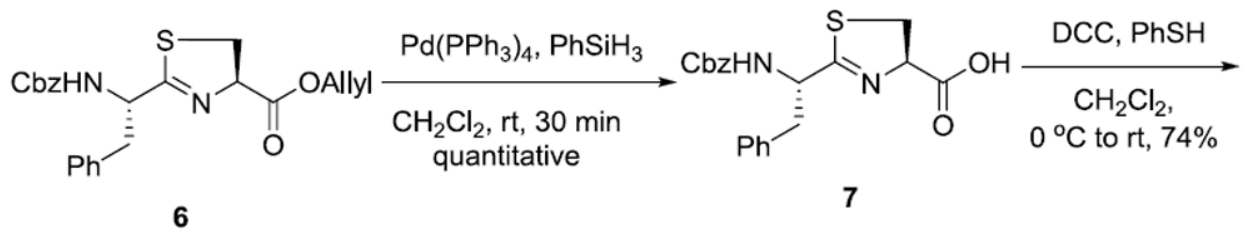

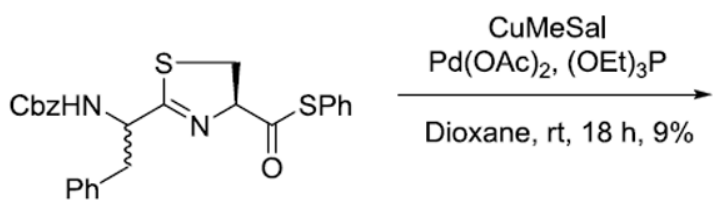

$2, d r=1.3: 1$<smiles>CC(C)(C)NC(=O)NC(Cc1ccccc1)c1nccs1</smiles>

rac-1

Scheme 2.

Synthesis of $\mathbf{r a c} \mathbf{- 1}$. 

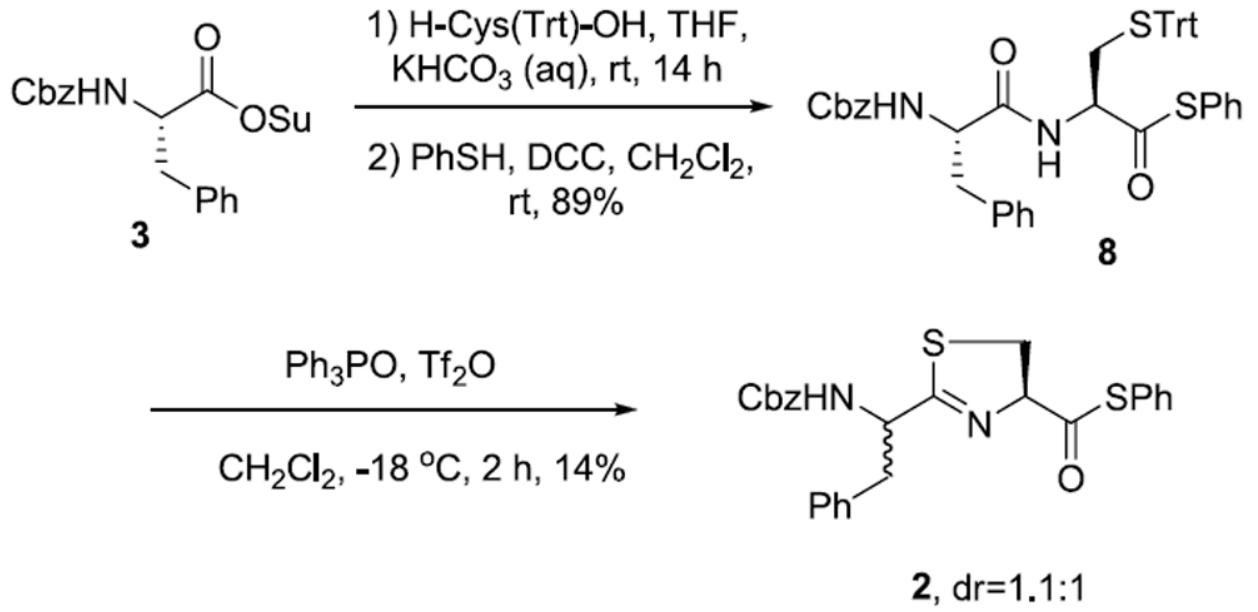

Scheme 3.

Cyclodehydration of thioester $\mathbf{8}$. 


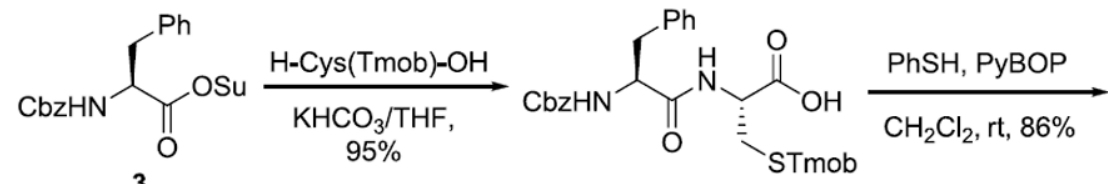

9

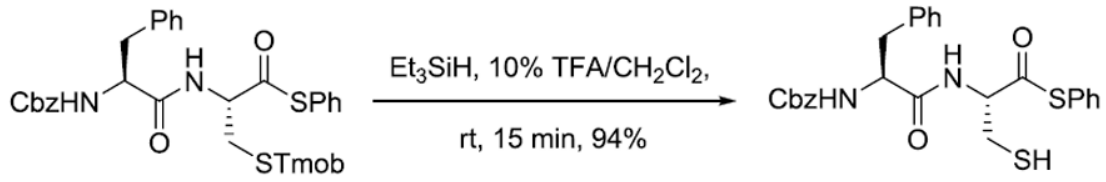
10

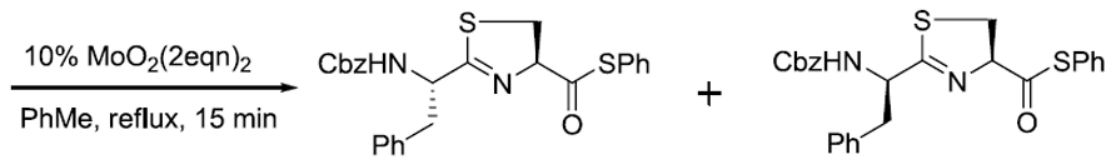

2, $76 \%$

$12,12 \%$

$$
\begin{aligned}
& 1.5 \text { equiv } \mathrm{Ni}\left(\mathrm{PPh}_{3}\right)_{4} \text {, } \\
& 1.2 \text { equiv CuTC } \\
& \text { Dioxane, rt, } 22 \mathrm{~h} \\
& 88 \%
\end{aligned}
$$<smiles>O=C(N[C@H](Cc1ccccc1)c1nccs1)c1ccccc1</smiles><smiles>O=C(NC(Cc1ccccc1)c1nccs1)c1ccccc1</smiles>

Z-(S)-dolaphenine (1)

Z-(R)-dolaphenine (13)

$[\alpha]_{D}=-21.3, \mathrm{c} 1.0, \mathrm{MeOH}$

$[\alpha]_{D}=+19.3, \mathrm{c} 1.0, \mathrm{MeOH}$

Scheme 4.

Stereoretentive synthesis of Z-(S)-Doe. 


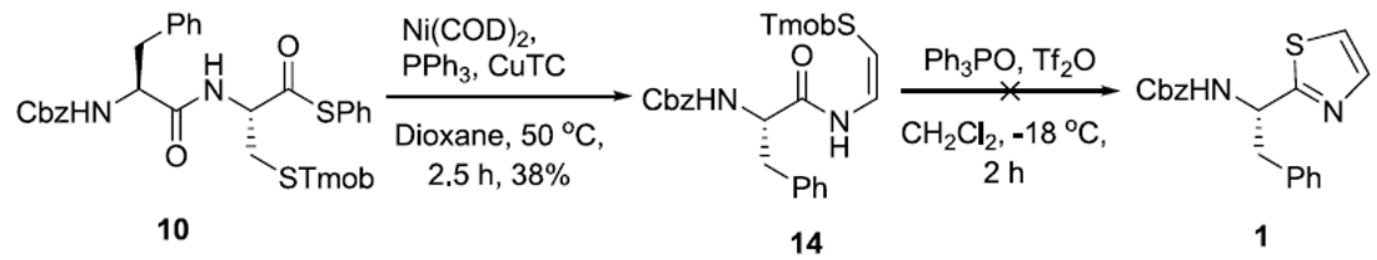

Scheme 5.

Attempted cyclodehydration of enamide $\mathbf{1 4}$. 